\title{
Гацалова Л.Б., Парсиева Л.К. \\ Лексика сферы делопроизводства в системном и лексикографическом аспектах (на материале осетинского языка)
}

Северо-Осетинский институт гуманитарных и социальных исследований им. В.И. Абаева филиал ФГБУН Федерального научного иеентра Владикавказский научный цеентр РАН

(Россия, Владикавказ)

doi: 10.18411/trnio-11-2021-194

\section{Аннотация}

В статье представлены результаты анализа и деятельности авторов по нормированию официально-деловой лексики осетинского языка. Сделаны выводы о необходимости проведения ряда научных исследований в аспекте лексикографии, определен комплекс мероприятий для организации системной работы по внедрению делопроизводства на осетинском языке в Республике Северная Осетия-Алания и Республике Южная Осетия с целью увеличения эффективности мер по сохранению родного языка.

Работа может быть полезна в практике документационного обеспечения управленческой деятельности на осетинском языке, а также в практике перевода.

Ключевые слова: осетинский язык, документационное обеспечение управления, документная лингвистика, делопроизводство.

\section{Abstract}

The article presents the results of the analysis and activity of the authors on the normalization of the official business vocabulary of the Ossetian language. Conclusions are drawn about the need to conduct a number of scientific studies in the aspect of lexicography, a set of measures is defined for the organization of systematic work on the introduction of office work in the Ossetian language in the Republic of North Ossetia-Alania and the Republic of South Ossetia in order to increase the effectiveness of measures to preserve the native language.

The work can be useful in the practice of documentation support of management activities in the Ossetian language, as well as in the practice of translation.

work.

Keywords: Ossetian language, documentation management, documentary linguistics, office

В современном мире бюрократии документационное обеспечение управления является одной из важнейших сфер жизни, касающейся каждого гражданина страны. Поэтому говорить об актуальности разработки терминологии делопроизводства на государственных языках излишне. Тем более приоритетно оно для языков так называемых «малочисленных народов», которые, в силу ограниченности областей функционирования их языков, пытаются, насколько это возможно в циничный период глобализации, увеличить возможности употребления и повысить престиж владения этими языками. Сделать это можно, как считают многие ученые и обыватели в хорошем смысле этого слова, при помощи внедрения в систему государственной службы делопроизводства на родном языке. Для этого органами исполнительной власти регионов принимаются соответствующие программы, построенные на идее сохранения языка и культуры титульной нации, с указанием мероприятий, направленных на разработку и систематизацию терминологии делопроизводства.

Сферами функционирования современного осетинского языка являются, в первую очередь, быт и семья, даже несмотря на расширение пользования им в образовательной деятельности. В последние годы осетинский язык является предметом изучения в дошкольных и школьных учреждениях образования с возможностью предоставления выбора варианта обучения на иронском или дигорском диалектах в зависимости от преобладающего в муниципальном образовании населения. Кроме того, во Владикавказе открыта Аланская 
гимназия, в которой обучение всем предметам в начальной школе ведется на осетинском языке с последующим переходом на русский. Другой сферой функционирования осетинского языка является религиозная обрядность: так как Осетия является многоконфессиональной республикой, и среди осетин есть представители православного христианства, мусульманства и традиционных верований, при совершении обрядов в большей или меньшей степени используется, помимо русского или арабского, также и осетинский язык. Так, например, осуществлен перевод Библии и многих других текстов, использующихся в богослужении.

Помимо этого, в Южной и Северной Осетии на осетинском языке выходят газеты и журналы, национальное телевидение и радиовещание, работают писательская организация и театры и т.д.

Признанным фактом является мнение ученых о том, что использование языка в области документведения снимает проблему сохранения этого языка [8, с. 167], внедрение в сферу делопроизводства сделало бы знание осетинского языка обязательным, по крайней мере, в такой престижной области, как государственная служба, а ведение рабочих заседаний органов исполнительной и законодательной власти Республики Северная Осетия-Алания и Республики Южная Осетия в том числе и на осетинском языке значительно бы повысило его статус. Всё это, однако, должно проводиться не спонтанно, а при системном подходе, включающем все уровни - от разработки терминологии и составления словарейсправочников по делопроизводству до включения в учебные планы программ высшего образования вузов республики дисциплин «Осетинский язык в профессиональной деятельности» и «Деловой осетинский».

Работа по разработке терминосистемы делопроизводства на иронском варианте осетинского языка ведется нами уже на протяжении нескольких лет, с тех пор, как мы занимались составлением переводных словарей [2, 7], а также русско-осетинского разговорника [4], в котором представлены разделы, так или иначе связанные с лексикой, касающейся обозначенной сферы деятельности. Кроме того, в осетинском языкознании имеется ряд научных трудов, авторы которых затрагивают проблемы формирования общественно-политической, юридической и экономической тематики, достаточно тесно соприкасающихся с терминологией управленческой деятельности и документационного обеспечения управления, в том или ином аспекте $[1,3,5,6]$.

В качестве направлений, которые мы хотим обозначить, как приоритетные, выделим следующие:

- составление бископального словаря-справочника по делопроизводству;

- составление реестра географических названий;

- составление реестра названий должностей;

- составление реестра названий учреждений;

- составление образцов документов.

При значительном количестве спорных вопросов необходимо проведение обсуждения не только в рамках научной дискуссии, но и среди журналистов, писателей и чиновников, ибо, как утверждал У. Лабов: «Если есть какие-либо разногласия по интроспективным суждениям, суждения тех, кто знаком с теоретическими вопросами, не могут считаться доказательствами» $[9$, с. 40$]$.

В лексикографической работе по составлению бископального словаря-справочника по делопроизводству целесообразно создание словника, включающего не только термины, непосредственно относящиеся к указанной отрасли, но и смежные, наиболее близко относящиеся, документоёмкие сферы деятельности. Например:

- в сфере юриспруденции: бездоказательный, бездействие, беззаконный;

— в сфере экономики: баланс, банк, безналичный;

- в социальной сфере: безнадзорный, безработный, бездомный.

Встречаются также и термины-омонимы, например акиия. 
АКЦИЯ ${ }^{1}$ акци (иенная бумага).

Именная акция. Номхуындон акции. Пакет акций. Акцииты пакет. Акция обыкновенная. Хуылметсег акци. Акция привилегированная. Уселдайбар акии. Акции поднялись. Акиитсе фоезынаргъдсер стыл. Акции упали. Акиитсе фоеасламджр стыл.

АКЦИЯ ${ }^{2}$ акци, архайд (действие, предпринимаемое для достижения какой-либо цели) (архайд).

Дипломатическая акция. Дипломатон акци. Военная акция. АЕфсседдон акии

Структура словарной статьи должна содержать не только сам термин и его перевод, но также максимальное количество наиболее употребительных словосочетаний с заглавным словом. Например, словарная статья с заглавным словом «акт» может содержать множество примеров:

ЕМАККАГ альтернативный.

Аммаккаг аевзарстытае. Альтернативные выборы. АЕмаккаг мадзаелттае. Альтернативные методы. Аммаккаг проект. Альтернативный проект. АЕмаккаг служббе. Альтернативная служба.

АМГЬУЫД срок.

Цыбыр аемгъуыдмае. На короткий срок. АЕмгъуыд фаци. Срок истёк. АЕмгъуыд фаеуыны фаеста. По истечении срока. АЕгъуыдма фаезынын. Явиться в срок. АЕмгъуыдма куыст сканын. Выполнить работу в срок. Фидыны аемгъуыды арххеццае. Наступление срока платежа. Авззжрстыты аемгъуыд. Сроки выборов. Документ аеххаст каныны аемгъуыд. Срок исполнения документа. АЕмгъуыдмае сконд заказ. В срок выполненный заказ. АЕмгъуыдмае бадзырд. Срочный договор. АЕмгъуыдма фи фиддан. Рассрочка. Телевизор семгъуыдмсе фиддансей балхснын. Купить телевизор в рассрочку.

Тем более это стоит делать, когда речь идет о заимствованиях в осетинский язык, например:

АКТ акт (документ, составленный несколькими лицами и подтверждающий установленные факты или события; имеет юридическое значение).

Акт аразын. Актировать. Акт саразын (скаенын). Составить акт, заактировать. Иртаесты акт. Акт дознания. Закъонсвсераег акт. Законодательньй акт. Азымджынганасн акт. Обвинительный акт. Мулкадаттыны акт. Акт о передаче имущества. Нотариалон акт. Нотариальный акт. Граждайнаг уавары акттк. Акты гражданского состояния.

АКЦЕПТ акцепт (согласие на предложение вступить в сделку, заключить договор на условиях, указанных в предложении; форма безналичного расчёта между организачиями).

АБбальырд акцепт. Акиепт неопределённый. Аввкрццсег акцепт. Акцепт положительный. АЕппарццае акцепт. Акцепт отрицательный. Банчы акцепт. Акцеет банковский. Вексель акцепт. Акцепт вексельный. Рагагъоммайы акцепт. Акцепт предварительный. Хыгъды акцепт. Акиепт счёта.

Слова, входящие в основной фонд языка, в сфере делопроизводства выступают в качестве терминов, в том числе и в устойчивых словосочетаниях, например:

АФАЕД год.

Афаедзсей афаезмке. Из года в год. Афадзы джргъы. В продолжение года, кругльий год. Афаедзы курсытае. Годичные курсы. Афаедз(ы) аемгъуыл. Годичный срок. Афадз раздар. Год тому назад. Афаеды аердаг. Полугодие. Афаедзыь фыццаг аррдаг. Первое полугодие. Афадзы дыккаг ардже. Второе полугодие.

В целом же документная лингвистика - явление относительно новое [8, 10]. В век бурного развития цифровых технологий и искусственного интеллекта основное внимание в этой области, как и везде, уделяется форме, шаблону. Поэтому значительную роль в разработке документной лингвистики играет составление образцов документов и шаблонов.

Заметим, что никакие теоретические разработки и практические пособия не будут эффективны без планомерной методико-дидактической работы, без специального обучения документоведов работе по составлению текстов профессиональной направленности, деловых 
писем, формированию банка офисной документации и т.п. Таким образом, подготовительная работа, направленная на внедрение делопроизводства на родном языке должна быть системной и многосторонней. Только тогда осетинский язык сможет функционировать в этой новой для себя сфере.

Исследование выполнено при финансовой поддержке РФФИ в рамках научного проекта № 21-512-07005 «Лексика государственного управления и делопроизводства на осетинском языке в системном и лексикографическом аспектах».

$* * *$

1. Гацалова Л.Б., Парсиева Л.К. Активные процессы в лексике и терминологии делопроизводства в условиях осетинско-русского двуязычия. - Владикавказ, 2019. 71 с.

2. Гацалова Л.Б., Парсиева Л.К. Большой русско-осетинский словарь. - Владикавказ: ИПО СОИГСИ, 2011. 685 c.

3. Гацалова Л.Б., Парсиева Л.К. Развитие общественно-политической, юридической и экономической терминосистем в современном осетинском языке // Современные проблемы науки и образования. 2014 . № 2. C. 547.

4. Гацалова Л.Б., Парсиева Л.К. Современный русско-осетинский разговорник. - Владикавказ: ИПО СОИГСИ, 2013. - $145 \mathrm{c}$.

5. Кульчиева М.Б. Вклад русского языка в становление и развитие общественно-политической терминологии осетинского языка. - Владикавказ, 2013. 116 с.

6. Малиева 3.Н. Тезаурусный метод исследования терминов обычного права // Современные тенденции развития науки и технологий. 2016. № 3-4. С. 54-58.

7. Парсиева Л.К., Гацалова Л.Б. Осетинско-русский, русско-осетинский словарь. - Владикавказ: Респект, 2018. $1296 \mathrm{c}$.

8. Agyeman, Nana Ama. 2019. Documenting Simpa: Advances in language documentation. Legon Journal of the Humanities 30(2): 167-190.

9. Labov, William. 1975. What is a linguistic fact? (PdR Press Publications in Linguistic Theory 1). Lisse: Peter de Ridder Press.

10. Thieberger, Nicholas. 2004. Documentation in practice: Developing a linked media corpus of South Efate. In Peter K. Austin (ed.), Language documentation and description, vol. 2, 169-178. London: SOAS.

\section{Герасименко И.В.}

Ирония в романе Х. Филдинг Bridget Jones: Mad About the Boy

Санкт-Петербургский университет управления технологий и экономики (Россия, Санкт-Петербург)

doi: 10.18411/trnio-11-2021-195

\section{Аннотация}

Предметом внимания в настоящей статье является описание способов выражения иронии в произведении Х. Филдинг «Дневник Бриджид Джонс. Без ума от мальчишки». Автор анализирует способы выражения иронии, как стилистического приёма, который проводился в соответствии с классификациями лексико-семантических и логико-синтаксических средств выраженияю.

Ключевые слова: Х. Филдинг, ирония как стилистический приём, лингвистические средства выражения иронии.

\section{Abstract}

The subject of attention in this article is a description of the ways of expressing irony in the work of H. Fielding "Diary of Brigid Jones. Crazy about the boy. " The author analyzes the ways of expressing irony, as a stylistic device, which was carried out in accordance with the classifications of lexical-semantic and logical-syntax means of expression.

Keywords: H. Fielding, irony as a stylistic device, linguistic means of expressing irony. 